Némethy, Judith Kesserü. “Cseh, Tibor. 2014. Csernátontól a Reménység Taváig: Válogatott írások ('From Csernáton to Lake Hope - Collected Writings'). Compiled and edited by Andrew Ludanyi. Budapest: Fekete Sas Publishers. 520 pp." Hungarian Cultural Studies. e-Journal of the American Hungarian Educators Association, Volume 9 (2016): http://ahea.pitt.edu DOI: 10.5195/ahea.2016.236

\title{
Cseh, Tibor. 2014. Csernátontól a Reménység Taváig: Válogatott írások ('From Csernáton to Lake Hope - Collected Writings'). Compiled and edited by Andrew Ludanyi. Budapest: Fekete Sas Publishers. 520 pp.
}

\section{Reviewed by Judith Kesserü Némethy, New York University}

The idea of transculturalism as a situation or position as well as a research tool was formulated already in the 1940s by Fernando Ortiz, a Spanish American thinker who was inspired by the writings of nineteenth-century Cuban national hero José Martí. Their concern was the mutual fertilization of ideas and experiences between the Northern and Southern Hemispheres, which could not but coincide with issues of colonialism and - later on postcolonialism. The case of Hungarian refugees and émigrés to the Western world following the fateful events that befell Hungary in the mid-twentieth century presents an interesting example of transculturalism within a multicultural and postcolonial setting. In the Hungarian instance of transcultural existence, namely of the conscious and often organized attempts of expatriate Hungarians to preserve their home culture including language, food ways, social activities and communal bonding, many of these practices were luckily documented in real time and thus enable researchers to reflect on their contribution to the cohesion of present-day communities of Hungarian descendants in both the Americas and Australia.

Andrew Ludanyi, a political-scientist at Ohio Northern University, has undertaken the important mission of compiling and editing the varied journalistic and personal-documentary writings of Tibor Cseh (1925-2004), a Hungarian émigré who dedicated much of his life to describing as well as encouraging the preservation of Hungarian culture among Hungarian émigrés, with special focus on youth movements and organizations. Thus the Cseh-Ludanyi book fills a vacuum in Hungarian Diaspora studies in its joint depiction and conception of a transcultural Hungarian community. Ludányi has compiled and edited a 520-page volume of Tibor Cseh's writings as part of the celebration of Cseh's life and activity on the occasion of the tenth anniversary of his death. The book includes a collection of articles and studies on the lives, challenges and responsibilities of Hungarians living outside the present borders of Hungary, be it as minorities within the Carpathian Basin since World War I or as diaspora throughout the Western world during the second half of the twentieth century. These writings reflect Cseh's deep commitment to the survival of the Hungarian language and culture beyond the borders of present-day Hungary.

Cseh's writings also follow his own migrations from his birthplace of Csernáton, in the Székely Land of Transylvania, through his teenage years and later university studies in Budapest, and finally his adventurous escape at the end of World War II from a train of Soviet prisoners-ofwar headed for Siberia. The Hungarian period in Cseh's life ended in 1948 after he was hounded by the political police (the infamous Államvédelmi Hatóság, ÁVH) for his activities in the student movement. He found shelter in an Upper-Austrian refugee camp, where he stayed until

(cc) $\mathrm{Br}$

ULLS D-Serle
New articles in this journal are licensed under a Creative Commons Attribution 4.0 International License.

This journal is published by the University Library System of the University of Pittsburgh as part of its D-Scribe Digital Publishing Program and is cosponsored by the University of Pittsburgh Press 
Némethy, Judith Kesserü. “Cseh, Tibor. 2014. Csernátontól a Reménység Taváig: Válogatott írások ('From Csernáton to Lake Hope - Collected Writings'). Compiled and edited by Andrew Ludanyi. Budapest: Fekete Sas Publishers. 520 pp." Hungarian Cultural Studies. e-Journal of the American Hungarian Educators Association, Volume 9 (2016): http://ahea.pitt.edu DOI: 10.5195/ahea.2016.236

he managed to board a ship headed to Rio de Janeiro, Brazil, as a Displaced Person. He soon married a fellow D.P. who was also a scout, and with her and two other scouts he organized the first Hungarian scout troop overseas. His professional life in Brazil started as an engineer in soil research, which landed him in a position as the representative of Central and South America in Cyanamid, a United-States-headed multi-national agricultural and industrial chemicals corporation. He was later transferred to the United States, to Cyanamid's headquarters in New Jersey. His position required long periods of stays in Mexico, Argentina, and back to Brazil, with shorter trips to Chile, Paraguay and Uruguay, until in 1968 he finally established his family in New Jersey. Yet Cseh's professional activity was only a small part of his endeavors; the center of his life was and always remained his commitment to cultural and community organizations of Hungarian émigrés and especially amongst their youth, for whom he was a tireless teacher and a genuine source of inspiration. Accordingly, his writings are dedicated to the cultural survival and preservation of the heritage and traditions of Hungarian immigrants in their new countries.

Cseh's opus spans three overriding topics: the challenges faced by the diaspora; the requirements for survival as Hungarians outside Hungary, and the duties of the Hungarian communities abroad. A constant concern in his writings about émigré-Hungarian culture is the antiquated political and religious divisions and loyalties often preserved by the older generations among the immigrants, but Cseh looks for unity beyond ideologies among émigrés, based on spiritual and cultural renewal. In all his writings he cherishes the nurturing of youngsters and thus the next generation becomes his overriding focus. Scouting, weekend language schools, reading clubs, organization of exhibits and dramatic presentations are his solution to dilemmas of old versus new and preservation as opposed to renewal. In the later part of his life, Cseh edited four important periodicals: two dealing with leadership and scouting (Vezetök Lapja and Magyar Cserkész); one, Itt-Ott, the organ of the Hungarian Community of Friends, and Transylvania, which addressed the history and acute problems faced by the Hungarian minority in this region. These publications made him the compass or activating yeast for generations of Hungarians who were pushed out of Central Europe following World War II and the 1956 Uprising, as well as for minorities in the Carpathian Basin suffering under Communist dictatorships. In other words, he inspired Hungarians who clung to their Hungarianness, whether they were living as expatriates in democracies or as minorities living under physical, psychological and emotional hardship.

Ludanyi, as the editor of Cseh's varied writings, has successfully divided Cseh's colorful life career and creeds into eight sections, each introduced by the editor's brief explanation of its historical or other background. These sections are: (1) Writings about Cseh's family history and personality; (2) The literary and cultural roots [of Cseh's writings], presenting role models such as Miklós Zrínyi, László Németh and Gyula Gombos; (3) The Transylvanian roots: the Székely Land [as a starting point to Cseh's thinking]; (4) Youth and the future of the Hungarian Scouting movement outside of Hungary, emphasizing the historical importance of the movement in the maintenance of the Hungarian ethos; (5) The question of emigration vs. diaspora, discussing the possibilities of community life in the emigration, or the ways Hungarian culture can be maintained; (6) A trans-denominational Hungarian religiosity, searching for a spirituality beyond ideologies, based on solidarity towards each other; (7) The cultural core of the Hungarian Communion of Friends, an organization of which Cseh is one of the co-founders; and (8) Cultural education, or the institutional and structural requirements for self-preservation in an 
Némethy, Judith Kesserü. “Cseh, Tibor. 2014. Csernátontól a Reménység Taváig: Válogatott írások ('From Csernáton to Lake Hope - Collected Writings'). Compiled and edited by Andrew Ludanyi. Budapest: Fekete Sas Publishers. 520 pp." Hungarian Cultural Studies. e-Journal of the American Hungarian Educators Association, Volume 9 (2016): http://ahea.pitt.edu DOI: 10.5195/ahea.2016.236

assimilationist environment. The volume concludes with farewell words delivered by Tibor Cseh's family, friends and colleagues on the occasion of his death in 2004 in Englewood, New Jersey as well as in 2005 in Csernáton, the Transylvanian Székely Land where his ashes were put to rest. The book also includes a name index and a selection of photographs of Cseh's family, friends and community. This book is of interest not only to members of the Hungarian diaspora worldwide but also to researchers of transculturalism, youth movements, community networks and trans-generational transference of Old Country legacies. 